\title{
Mmatshilo Motsei 2007: The kanga and the kangaroo court - reflections on the rape trial of Jacob Zuma. Jacana, Cape Town.
}

Contemporary interpretations of African culture are responsible for objectifying women. This is Mmatshilo Motsei's conclusion after profound reflections on the implications of Jacob Zuma's rape trial in which he was accused of raping the daughter of his comrade who died in exile.

In the trial Zuma claimed that the sexual encounter was consensual. When explaining his submission to passion and failing to use a condom, he said that had he left the woman sexually unfulfilled, in Zulu culture he could be accused of rape. He further denied that he had a father-daughter relationship with the rape complainant who was known as Khwezi in the trial.

In this book the author asserts that by denying the father-daughter relationship, Zuma was being disingenuous. 'As someone who has a keen eye and ear for tradition,' writes Motsei (2007:15), 'he is aware of the principle of "my child is your child, you child is mine", which, in African societies, encourages biological and non-biological parents to take communal responsibility for the material, psychological and moral wellbeing of every child in the community'.

As someone who claims to subscribe to a 'strong belief in ancestors', Motsei (2007: 15) further notes: 'Zuma must have known that the wrath of the spirit of his comrade who died in exile leaving behind a distraught ten-year-old daughter might come back to haunt him'.

While the book's point of departure is Zuma's rape trial, the book examines the degradation of women in general, where culture and religion are used as an excuse to oppress women.

Motsei demonstrates through thorough research that the role of women in African culture was historically not limited to being child bearers: 'They are, according to the elders, the ones who communicate with the spirits during rituals. According to Venda custom, a man's sister, makhadzi, is the one chosen to speak with the ancestors on behalf of his family or community. In Tswana, Pedi and Sotho cultures, rakgadi plays the same role' (Motsei, 2007: 77).

How then, did it come about that with such a historical background some African men came to be female bashers? There are many factors, both endogenous and exogenous, which space does not allow to elaborate on here.

Moaning is not what this book is about - it is a call to action. Motsei points out that the mere introduction of progressive legislation is not the solution. Progressive laws, she strongly believes, should be accompanied by widespread education and campaigns that will eliminate socio-cultural myths that perpetuate rape in our society.

Reinterpretation of African culture will liberate sexist men from their misogynistic tendencies, and empower submissive women to become confident and assertive. This book is a must for all those who are committed to a just society where men and women will live as partners and not as adversaries. It is especially for African men who have lost touch with their roots and have become reduced to instinctive animals with no selfcontrol.

\section{Simphiwe Sesanti, Lecturer, Department of Journalism, Stellenbosch University}

